Available online at https://jurnal.stmikroyal.ac.id/index.php/jurdimas

\title{
IMPLEMENTASI PENDETEKSI KUALITAS AIR PADA TAMBAK UDANG VANAME DI DI KEC. HAMPARAN PERAK DELI SERDANG
}

\author{
Jhonson Efendi Hutagalung* ${ }^{1}$, Hilda Julia ${ }^{2}$, Aisar Novita ${ }^{3}$ \\ ${ }^{1,}$ Teknik Komputer, STMIK Royal Kisaran \\ ${ }^{2}$ Teknik Tanah dan Air, Unimed Medan \\ ${ }^{3}$ Cekaman Lingkungan, Unimed Medan \\ email:*jhonefendi12@yahoo.co.id
}

\begin{abstract}
The increasing demand for seafood resources in Indonesia has prompted the government to take steps to increase seafood production by developing brackish water aquaculture in coastal areas. One of them is by developing a round pond sheeting community ponds business. The choice of tarpaulin system round is considered one of the solutions that is quite effective and efficient considering that there are some constraints or limitations that are owned by the community, especially in the Village of Paluh Manan. Some of these problems include the limited number and suitability of land, capital, fry quality, disease growth, information and technology. In addition, there is an assumption in the community that vaname shrimp farming will be profitable if it is cultivated semi-intensively and intensively which in its operation requires a large enough investment. Answering this problem, through the implementation of vaname shrimp culture using a round tarpaulin, the community has directly cut the cost of purchasing land and making ponds. Furthermore, through the application of water quality detection technology in the probiotic application, concerns about the low success rate because the fries are prone to death either due to water mismatches or due to diseases (viruses and bacteria) can be minimized as much as possible.
\end{abstract}

Keywords: Aquaculture, Vaname Shrimp, Round Tarps Ponds, Detectors, Water Quality

\begin{abstract}
Abstrak: Meningkatnya permintaan akan sumberdaya pangan laut di Indonesia telah mendorong pemerintah untuk mengambil langkah-langkah menambah produksi pangan laut dengan mengembangkan budidaya perikanan air payau di wilayah pesisir. Salah satunya dengan pengembangan usaha tambak masyarakat sistem terpal bundar. Pemilihan sistem terpal bundar dianggap salah satu solusi yang cukup efektif dan efisien mengingat adanya beberapa kendala atau keterbatasan yang dimiliki oleh masyarakat khususnya di Desa Paluh Manan. Beberapa permasalahan tersebut diantaranya adalah keterbatasan jumlah dan kesesuaian lahan, modal, kualitas benur, pertumbuhan penyakit, informasi dan teknologi. Selain itu, adanya anggapan di masyarakat bahwa budidaya udang vaname akan menguntungkan jika dibudidayakan secara semi intensif dan intensif yang dalam pengoperasiannya memerlukan investasi cukup besar. Menjawab permasalahan ini, melalui penerapan budidaya udang vaname menggunakan terpal bundar maka masyarakat secara langsung sudah memangkas biaya pembelian lahan dan pembuatan tambak. Selanjutnya, melalui penerapan teknologi pendeteksi kualitas air pada aplikasi probiotik maka kekhawatiran akan tingkat keberhasilan yang rendah karena benur rentan mati baik akibat ketidaksesuaian air maupun akibat penyakit (virus dan bakteri) dapat diminimalisir semaksimal mungkin.
\end{abstract}

Kata kunci: Budidaya, Udang Vaname, Kolam Terpal Bulat, Pendeteksi, Kualitas Air 
Available online at https://jurnal.stmikroyal.ac.id/index.php/jurdimas

\section{PENDAHULUAN}

Kabupaten Deli serdang merupakan salah satu kabupaten di Propinsi Sumatera Utara yang sebagian besar wilayahnya merupakan kawasan pesisir, dalam laporan Dinas Kabupaten Deli Serdang (2009) bahwa luas areal pesisir pantai mencapai \pm 63.002 Ha. Kecamatan Hamparan Perak salah satunya, dijadikan sebagai pusat pengembangan kawasan tambak yang apabila dikelola dengan terpadu akan memberikan manfaat jangka panjang bagi masyarakat/penduduknya. Selama proses pengembangan kawasan tambak di Kecamatan Hamparan Perak tersebut, terdapat beberapa kendala atau permasalahan yang sering menjadi faktor kegagalan atau penurunan minat petani dalam kegiatan budidaya udang vaname. Permasalahan tersebut diantaranya adalah: a. Modal. Adanya anggapan masyarakat bahwa budidaya udang vaname memerlukan investasi atau modal yang besar agar dapat mendatangkan manfaat ekonomi.

b. Lahan, menyangkut luasan dan kondisi fisik (kualitas lahan). Perlu teknologi yang dapat diterapkan di lahan terbatas, dan bebas dari logam berat/toksik

c. Kualitas air.

d. Penyakit (virus dan bakteri).

Permasalahan di atas merupakan faktor yang melatarbelakangi perlunya Pengembangan Budidaya Udang Vaname (Lithopenaeus vannamei) di Kolam Terpal Bundar dengan Teknologi Pendeteksi Kualitas Air pada Aplikasi Probiotik sebagai suatu solusi yang menjawab semua permasalahan di atas. Untuk Teknologi Aplikasi Probiotik ini sebelumnya sudah pernah diterapkan di Pusat Penelitian dan Pengembangan Budidaya Air Payau (Maros, Sulawesi Selatan).

Permasalahan utama di kelompok petani mitra adalah lambatnya informasi sampai ke tingkat petani mengenai budidaya udang vaname di kolam terpal bundar yang terintegrasi dengan penggunaan probiotik sebagai solusi untuk mencapai kesesuaian air pemeliharaan. Kesesuaian air dapat dipertahankan karena tidak adanya interaksi antara tanah dan air yang menyebabkan pertumbuhan penyakit dapat diminimalisir, selain itu probiotik mampu mengembangkan bakteri-bakteri yang menguntungkan di dalam air, mampu bertindak sebagai pengurai sisa limbah pakan dan sekaligus mampu menjaga keseimbangan mikrobiota di saluran pencernaan udang. Untuk mempertahankan kesesuaian air maka dibutuh alat indikator pemberitahuan kesesuai tersebut. Hal ini yang menjadi pokok permasalahan di kelompok petani mitra selama ini sehingga pertumbuhan dan perkembangan jaringan bisnis udang vaname hanya terbatas dalam skala tambak yang luas. Kelompok petani mitra tidak memahami konsep dan prinsip kerja bertambak dengan kolam terpal bundar yang efektif dan efisien termasuk di dalamnya hal-hal yang berkaitan dengan probiotik, yaitu: 1. Bagaimana bentuk konstruksi bangunan yang digunakan. 2. Dari mana diperoleh bahan terpal dan rangka konstruksinya. 3. Apa jenis bahan terpal dan rangka konstruksi yang digunakan. 4. Berapa jumlah biaya yang digunakan. 5. Bagaiman sistem kerja sensor untuk mendeteksi kesesuain air. 6. Apa jenis probiotik yang digunakan. 7. Waktu dan cara pengaplikasian probiotik yang benar.

\section{METODE}

Metode yang ditawarkan untuk mengatasi persoalan yang ada di kelompok petani mitra adalah:

1. Membangun dempond terpal bundar sebagai sarana yang tepat untuk melakukan bimbingan teknologi dalam budidaya udang vaname.

2. Melakukan Desiminasi Teknologi Pengembangan Budidaya Udang Vaname (Lithopenaeus vannamei) di Kolam Terpal Bundar dengan Teknologi Pendeteksi Kualitas Air pada Aplikasi Probiotik.

Luaran yang diperoleh dari pelaksanaan kegiatan ini adalah: 
Available online at https://jurnal.stmikroyal.ac.id/index.php/jurdimas

1. Peningkatan minat petani dalam budidaya udang vaname menggunakan kolam terpal bundar semakin tinggi dengan kelengkapan sistem sensor kualitas air.

2. Pemanfaatan lahan sempit nonproduktif menjadi lahan yang produktif.

3. Peningkatan kualitas Sumber Daya Manusia di kalangan kelompok petani mitra.

Rencana capaian yang diharapkan dari kegiatan ini adalah terciptanya peningkatan kesejahteraan ekonomi dan kualitas lingkungan sosial di daerah kelompok petani mitra. Hal ini dapat dilihat dari keberhasilan indikator-indikator capaian sebagai berikut:

1. Peluang keberhasilan budidaya udang vaname dengan terpal bundar dan aplikasi probiotik semakin besar dengan angka kehidupan pemeliharaan semakin meningkat.

2. Konversi pakan semakin rendah.

3. Pertumbuhan udang semakin cepat.

4. Peningkatan kualitas dan produksi semakin tinggi.

\section{PEMBAHASAN}

\section{Pembuatan Wadah Kolam}

Tahapan pelaksanaan kegiatan yaitu:

1. Pembuatan Dempond dengan melibatkan partisipasi kelompok petani mitra.

a. Persiapan lahan di dua tempat (dua kelompok mitra) masing-masing berukuran 10 x $10 \mathrm{~m} 2$ untuk letak susunan kolam terpal bundar. Masing-masing dempond terdiri dari tiga unit kolam terpal bundar, dua diantaranya digunakan untuk budidaya sedangkan sisanya untuk tandon cadangan air.

b. Rangkaian kerja pembuatan kolam terpal bundar

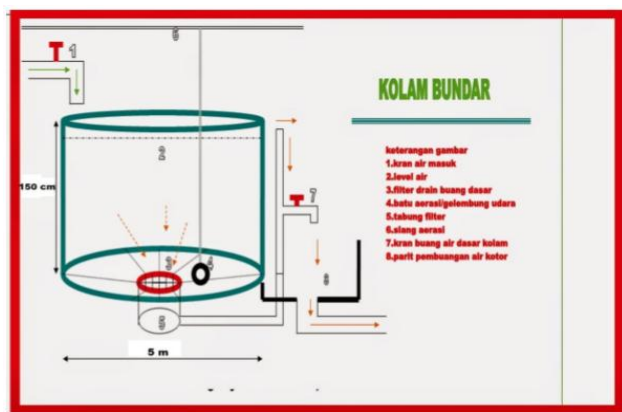

Gambar 1. Konstruksi Kolam Terpal

c. Ringkasan teknik budidaya

- Setelah fisik kolam selesai dibangun maka setiap kolam terpal bundar sudah dapat diisi dengan air laut dengan salinitas 15-20 ppt.

- Kedalaman air dalam kolam 80-90 cm.

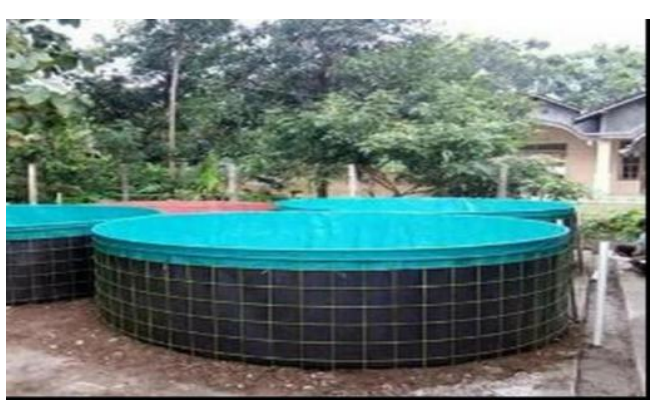

Gambar 2. Kolam Bundar Terpal

- Air kolam kemudian disterilkan dengan kaporit (konsentrasi 60 ppm).

- Dua hari kemudian aerator diaktifkan guna menghilangkan aroma atau residu kaporit dalam air.

- Setelah residu kaporit diyakini hilang maka air ditaburi dolomit dengan takaran $0,5 \mathrm{ppm}$.

- Berselang satu hari setelah ditaburi dolomit, probiotik dilarutkan ke dalam air dengan takaran $2 \mathrm{ppm}$. Proses aerasi terus berlangsung selama 10-15 hari.

- Setelah kondisi air sesuai dengan air budidaya udang, maka benur segera dimasukkan ke dalam kolam dengan padat tebar 300-400 ekor/m2 atau sekitar 800010000 ekor/kolam.

- Pengamatan terus dilakukan setelah 24 jam terhitung sejak benur masuk ke kolam, selanjutnya perlu dilakukan penaburan pakan tipe starter sebagai 
Available online at https://jurnal.stmikroyal.ac.id/index.php/jurdimas

pengenalan bagi benur udang. Pemberian ini berlangsung selama satu minggu.

- Pembuatan sensor pendeteksi kualiatas air dengan penyesuaian air yang di butuhkan dalam pemenuhan makanan ikan dan sensor ketinggian air sehingga kapasitas air dapat di amati secara otomatisasi.

- Perlakuan probiotik diaplikasikan sekali dalam tiga hari (kondisional) tergantung kepadatan plankton yang ada di dalam air kolam.

- Pertukaran tipe pakan dilaksanakan pada umur 7-8 hari (digunakan pakan 01) dan juga dilakukan penambahan kedalaman air kolam menjadi $1 \mathrm{~m}$.

- Pada minggu ketiga dan keempat pakan bertukar/naik grade menjadi pakan 02 . Dengan waktu bersamaan proses penyedotoran kotoran sudah bisa dilakukan setiap hari dan penambahan air juga dilakukan sesuai dengan kebutuhan.

- Peningkatan dosis pakan disesuaikan dengan indikator anco

- Setelah udang berumur satu bulan sampai Lampu Led akan diganti menjadi pakan 03 sampal uuang berumur dua bulan.

- Pada saat udang berumur lebih dari dua bulan maka pakan yang diberikan adalah pakan 04.

- Pakan finisher diberikan saat udang berumur diatas tiga bulan sampai panen. Pada saat udang berumur tiga bulan, perlu pengamatan yang lebih serius tentang kualitas air karena penurunan kualitas air sering terjadi pada waktu menjelang panen.

- Kalau udang sehat dan kualitas air mendukung maka pemeliharaan udang berlangsung selama 120 hari.

2. Desiminasi teknologi budidaya udang vaname menggunakan kolam terpal bundar dan aplikasi probiotik kepada kelompok petani mitra beserta serah terima peralatan perangkat budidaya masing-masing kelompok.

3. Monitoring dan evaluasi kelompok petani mitra.

Dibutuhkan suatu pengujian terhadap rancangan rangkaian yang telah dibuat. Sehingga dapat menghasilkan sistem yang bekerja sesuai dengan perintah yang diberikan melalui sensor. Sistem ini digunakan untuk mendeteksi tingkat kualitas air. Tingkat Kualiatas Air adalah berdasarkan $\mathrm{Ph}$ Air yang dikomsumsi oleh udang vaname.

Dimana sensor akan mendeteksi kualitas air dengan merubahnya menjadi tegangan yang dibangkitkan oleh sensor. Sinyal yang berubah ubah yang dihasikan deteksi dari sensor di berikan ke pada inputan pada mikrokontroler arduino uno. Sinyal yang diterima akan mengaktifkan Arduino sesuai dengan program yang telah disimpan. Arduino akan mengeluarkan tegangan ke driver sehingga driver akan menampilkan harsil proses ADC dari program yang dijalankan oleh Arduino. Nilai akan ditampilkan pada LCD sesuai dengan tingkatan $\mathrm{Ph}$ air yang terdeteksi oleh sensor.

$\mathrm{Ph}$ sensor ini membaca nilai $\mathrm{PH}$ air dan merobahnya kedalam tegangan analog, tapi dikuatin dulu lewat IC OP-Amp.

Sepertinya sudah dapat kita lihat kebanyakan modul sensor PH seperti gambar dibawah ini. yang mana pada ujungnya dipasangkan sebuah connector BNC yang nantinya di hubungkan probe sensornya, sehingga langsung terhubung ke input mikrokontroler, yang terdiri dari bagian input dan output DC.

Gambar masing-masing rangkaian dapat dilihat pada gambar di bawah ini:

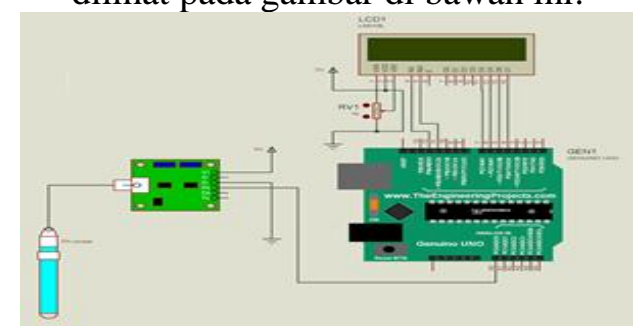

Gambar 3. Desain Sensor Ph Air

$\begin{array}{ccc}\text { Rancangan } & \text { sistem minimum ini } \\ \text { berfungsi } & \text { untuk } & \text { mengaktifkan }\end{array}$ mikrokontroler agar dapat bekerja sesuai dengan program yang telah dirancang. Didesain dengan menggunakan software penggambaran rancangan elektronik seperti eagle maupun circuit wizard. Tata letak 
Available online at https://jurnal.stmikroyal.ac.id/index.php/jurdimas

komponen disesuaikan sehingga dapat lebih sederhana.

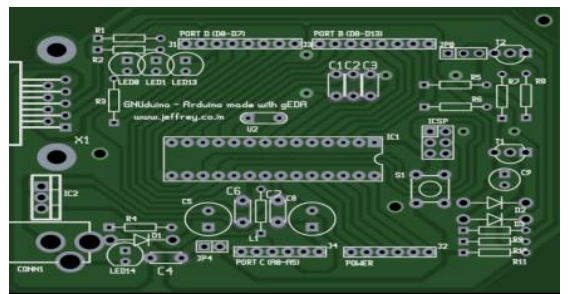

Gambar 4. Perancangan PCB layout Sistem Minimum Mikrokontroler

Rancangan untuk menyediakan $5 \mathrm{~V}$ yang nantinya dihubungkan dengan lampu Led sehingga dapat mendeteksi terjadinya penurunan atau kenaikan teganganRancangan relay ini terdiri dari sebuah relay yang dirangkaikan dengan resistor $1 \mathrm{~K}$, transistor $\mathrm{C} 9014$, sehingga menjadi penggerak relay untuk menghubungkan arus ke lampu led yang diberikan input-an dari mikrokontroler Arduino. Gambar rancangan desain rangkaian relay dapat dilihat pada gambar 3.11 .

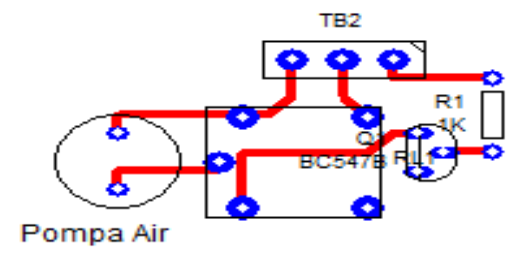

\section{Gambar 5. Desain PCB Rangkaian Relay}

Alat kontrol yang akan di bangun adalah untuk mendeteksi kualitas air

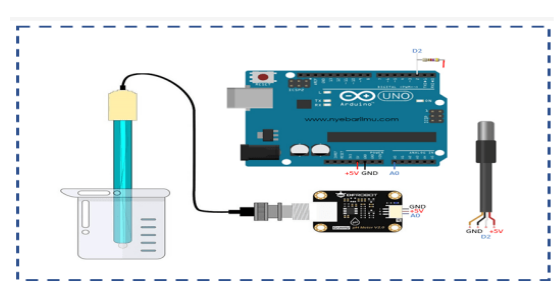

Gambar 6. Desain Alat Kontrol Kualitas Air

Program diuji dilakukan dengan mengisikan program yang telah di rancang dengan menggunakan aplikasi arduino ide. Setelah diverifikasi apakah program sesuai atau tidak error maka program di download ke IC program arduino uno.

Tabel 1. Hasil Pemasangan Alat

\begin{tabular}{|c|c|c|c|}
\hline \multirow{2}{*}{ No } & \multirow{2}{*}{ Kondisi } & \multicolumn{2}{|c|}{ Berat udang } \\
\cline { 3 - 4 } & $\begin{array}{l}\text { Awal (g) } \\
\text { PL 10 }\end{array}$ & $\begin{array}{l}10 \\
\text { hari }\end{array}$ \\
\hline 1 & $\begin{array}{l}\text { Sebelum } \\
\text { dipasang sensor }\end{array}$ & 0,001 & 0.30 \\
\hline 2 & $\begin{array}{l}\text { Sebelum } \\
\text { dipasang sensor }\end{array}$ & 0,001 & 0,40 \\
\hline
\end{tabular}

Melalui penerapan teknologi pendeteksi kualitas air pada aplikasi probiotik maka kekhawatiran akan tingkat keberhasilan yang rendah karena benur rentan mati baik akibat ketidaksesuaian air maupun akibat penyakit (virus dan bakteri) dapat diminimalisir. Tetapi dengan ada pendeteksi kualitas air tersebut bahwa terjadi peningkatan berat badan benur berdasarkan ada tidaknya teknologi yang digunakan pada kolam udang vaname tersebut.

Sehingga untuk panen udang PL 60 (60 hari) maka diperoleh berat udang $24 \mathrm{~g} /$ per ekor.

\section{SIMPULAN}

Dari pembahasan pada bab-bab sebelumnya dapat diambil kesimpulan, yaitu : Rencana capaian yang diharapkan dari kegiatan ini adalah terciptanya peningkatan kesejahteraan ekonomi dan kualitas lingkungan sosial di daerah kelompok petani mitra. Hal ini dapat dilihat dari keberhasilan indikator-indikator capaian sebagai berikut:

1. Peluang keberhasilan budidaya udang vaname dengan terpal bundar dan aplikasi probiotik semakin besar dengan angka kehidupan pemeliharaan semakin meningkat.

2. Konversi pakan semakin rendah.

3. Pertumbuhan udang semakin cepat.

4. Peningkatan kualitas dan produksi semakin Tinggi semaksimal mungkin. Keberhasilan dari kegiatan ini ditargetkan dapat meningkatkan minat masyarakat setempat 
Jurdimas (Jurnal Pengabdian Kepada Masyarakat) Royal

Vol. 3 No. 1, Januari 2020, hlm. 1 - 6

DOI: https://doi.org/10.33330/jurdimas.v3i1.435

ISSN 2622-3813 (Online)

Available online at https://jurnal.stmikroyal.ac.id/index.php/jurdimas

yang ditandai dengan bertambahnya jumlah petani tambak sistem terpal bundar di desa Paluh Manan yang akhirnya turut meningkatkan jumlah produksi udang vaname di tingkat desa maupun di tingkat kecamatan dan mampu bersaing di tingkat ekspor.

\section{UCAPAN TERIMA KASIH}

Terimakasih kami ucapkan kepada Kemenristekdikti dengan program Diseminasi Produk Teknologi Untuk Masyarakat (PDTM) yang memberikan dana hibah kepada kami dan juga kepada yayasan perguruan teladan asahan yang telah memberikan dukungan kepada kami. Dukungan dana dan fasilitas ini yang kami terima akan kami manfaatkan untuk pelaksanaan pengabdian ke pada masyarakat dengan sebaik baiknya

\section{DAFTAR PUSTAKA}

Bambang Widyo Prastowo, dkk. "Kontrol Nitrogen Anorganik Untuk Mengendalikan Nitrogen Bentuk Beracun (Nh3 ) Pada Tambak Udang Vaname (Litopenaeus Vannamei) Dengan Menggunakan Gabungan Molase Dan Probiotik". Jurnal Perekayasaan Akuakultur Indonesia, Volume 1 Nomor 2, ISSN: 2614-3348 Juni
2018.

Dr. M. Narayana. "Voice Control Robot using Android Aplication", International Journal Of Enggineering Innovation \& Research, Vol. 4, Issue 2 ISSN: 2277- 5668, 2014

Davis F. Sumajouw, "Perancangan Sistem Keamanan Rumah TInggal Terkendali Jarak Jauh",E- journal Teknik Elektro dan Komputer, ISSN : 2301-8402, 2015.

Devid Prastyawan, "Implementasi Model Robot Edukasi Menggunakan Mikrokontroler Atmega8 Untuk Robot Pemadam", Apijns- Indonesian Journal on Networking and Security ISSN: 2302- 5700, 2012.

Muhammad Ichwan, Pembangunan Prototipe Sistem Pengendalian Peralatan Listrik Pada Platform Android" Jurnal Informatika. No.1. Vol.4 Januari 2013. ISSN: 2087-5266, 2013.

Rafiuddin Syam, PhD, "Dasar-dasar Teknik Sensor". Fakultas Teknik Univ.Hasanuddin, 2013.

Sulastri Arsad, dkk, "Studi Kegiatan Budidaya Pembesaran Udang Vaname (Litopenaeus Vannamei) Dengan Penerapan Sistem Pemeliharaan Berbeda", Jipk Vol.9 No.1 , April2017 Diterima/ Submitted : 25 Desember 2016 Disetujui/ Accepted : 9 Maret 2017. 